\title{
PENINGKATAN KOMPETENSI MANAJERIAL PRAJURU DESA ADAT DAN PENGELOLA LPD DI DESA BATUBULAN KECAMATAN SUKAWATI KABUPATEN GIANYAR
}

\author{
N.W. Suniti ${ }^{1}$, W.P. Windia ${ }^{2}$, N.L.R. Purnawan ${ }^{3}$, dan I.A. Arthayani ${ }^{4}$
}

\begin{abstract}
ABSTRAK
Kegiatan pengabdian kepada masyarakat ini bertujuan untuk meningkatkan kompetensi manajerial Prajuru Desa Adat dan sumber daya pengelola LPD melalui pelatihan dan pendampingan tentang awig-awig (peraturan), administasi keuangan Desa Adat. dan laporan keuangan LPD. Kehidupan sosial masyarakat sangat dipengaruhi oleh aktifitas masyarakat adat yang tergabung dalam Desa Adat Batubulan dan Singapadu kecamatan Sukawati Kabupaten Gianyar. Metode yang diterapkan dalam pemberdayaan masyarakat pada kegiatan Ibw (Iptek bagi Wilayah) adalah sebagai berikut : (1) Koordinasi dan komunikasi secara partisipasif dengan kelompok tani untuk membuat program mulai dari perencanaan, operasional dan evaluasi; (2) Penyuluhan untuk menyamakan persepsi dan pemahaman masyarakat mengenai inovasi atau program yang diterapkan; (3) Pelatihan untuk meningkatkan untuk meningkatkan manajerial prajuru desa adat dan pengelola LPD; (4) Pendampingan yaitu pertemuan secara berkelanjutan antara pendamping dengan masyarakat sasaran sehingga iptek yang dialihkan dapat dilaksanakan secara mandiri oleh masyarakat. Hasil yang diperoleh menunjukkan bahwa kegiatan desiminasi iptek bagi wilayah di Desa Batubulan, kecamatan Sukawati, Kabupaten Gianyar dapat berlangsung dengan baik, adanya partisipasi aktif masyarakat dan adopsi iptek yang tinggi. Partisipasi aktif mitra pada seluruh kegiatan cukup tinggi
\end{abstract}

Kata Kunci : iptek, prajuru desa adat, pengelola LPD.

\begin{abstract}
Community service activities aimed at improving the managerial competence of customary village counselors and LPD management resources through training and assistance on awig-awig (regulation), customary village financial administration. and LPD financial reports. The social life of the community is strongly influenced by the activities of indigenous people who are members of indigenous villages of Batubulan and Singapadu Sukawati sub-district of Gianyar Regency. The methods applied in community empowerment in Ibw (Science and Technology for Territory) activities are as follows: (1) Participatory coordination and communication with farmer groups to create programs ranging from planning, operations and evaluation; (2) Counseling to equate people's perceptions and understanding of innovations or programs implemented; (3) Training to improve to improve managerial of custom village counselors and LPD managers; (4) Assistance is a continuous meeting between the assistant and the target community so that the transferred science and technology can be implemented independently by the community. The results show that science and technology dissemination activities for Batubulan village, Sukawati sub-district, Gianyar regency can take place well, active participation of society and high adoption of science and technology. Active participation of partners on all activities is quite high.
\end{abstract}

${ }^{I}$ Staf Pengajar Fakultas Pertanian Universitas Udayana, sunitiwayan@ gmail.com

${ }^{2}$ Staf Pengajar Fakultas Hukum Universitas Udayana

${ }^{3}$ Staf Pengajar FISIP Universitas Udayana

${ }^{3}$ Staf Pengajar ISI Denpasar 
Key words : science and technology, prajuru desa adat, LPD management

\section{PENDAHULUAN}

Desa Batubulan dan Singapadu Kecamatan Sukawati dalam RPJM Kabupaten Gianyar ditetapkan sebagai desa wisata yang mengalami pertumbuhan penduduk yang sangat pesat sehingga memicu berbagai persoalan adat yang membutuhkan kompetensi prajuru (pengusus desa adat) tentang hukum adat dan penyelesaian kasus adat yang memadai. Strategi yang diambil oleh Pemerintah Kabupaten Gianyar untuk mengatasi hal tersebut adalah dengan memberi pelatihan dan pendampingan prajuru (pengurus) adat tentang awig-awing (peraturan) dan administrasi desa adat serta peningkatan kapasitas sumberdaya manusia pengelola LPD pelatihan dan pendampingan dalam pembuatan laporan keuangan. Permasalahan yang dihadapi oleh masyarakat adalah lemahnya sumberdaya pengelola desa adat dalam penyelesaian sengketa adat dan LPD sebagai nadi ekonomi kerakyatan belum digarap secara optimal karena profesionalisme sumberdaya manusia pengelola LPD yang sangat rendah.

\section{METODE PELAKSANAAN}

Metode

Metode yang diterapkan dalam pemberdayaan masyarakat pada kegiatan IbW adalah sebagai berikut : (1) Koordinasi dan penyuluhan untuk membangun persepsi dan pemahaman masyarakat mengenai inovasi atau program yang diterapkan, (2) Pelatihan dan simulasi mengenai terapan iptek yang dialihkan bagi masyarakat dan (3) Pendampingan yaitu pendampingan secara berkala dan berkelanjutan antara pendamping dengan masyarakat.

Tahapan Kegiatan

Pelaksanaan kegiatan IbW mulai dari koordinasi dan komunikasi secara partisipasif dengan masyarakat sasaran untuk merumuskan program mulai dari perencanaan, operasional dan evaluasi.

(1) Peyuluhan tentang pentingnya pembuatan awig-awig (aturan) dan alih teknologi pemetaan partisipasif (peta batas wilayah desa adat)

(2) Pelatihan untuk meningkatkan manajerial sumberdaya manusia pengelola LPD sebagai nadi ekonomi kerakyatan dan sumber pembiayaan aktifitas desa adat.

Pembuatan kebun bibit dan pendampingan produksi bibit dari stek pucuk melalui bimbingan teknis secara berkala dengan kelompok petani dan memberikan kesempatan untuk konsultasi menyangkut solusi dari berbagai persoalan terkait dengan aplikasi teknologi tersebut.

\section{HASIL DAN PEMBAHASAN}

Kegiatan yang telah diakukan pada program IbW di Desa Batubulan dan Desa Singapadu tahun ke 2 (2017) meliputi 4 kegiatan yaitu :

1. Koordinasi kegiatan IbW dengan Bappeda Kabupaten Gianyar dan Instansi terkait Sosialisasi dilaksanakan pada tanggal 2 Juni 2017 di Kantor Bappeda Kabupaten Gianyar dihadiri oleh 30 orang diantaranya : Tim IbW Unud, Badan Pemberdayaan Masyarakat Desa, Dinas Pertanian , Perindustrian dan Perdagangan, Badan Hukum dan Ham, Kepala Dinas Tata Pemerintahan ,Bagian Ekonomi Bappeda , Dinas Koperasi, dan Badan Lingkungan Hidup Kabupaten Gianyar . Kegiatan ini bertujuan untuk membahas tentang rencana kegiatan IbW di Desa Batubulan dan Singapadu tahun ke 2 (2017) yang meliputi : Koordinasi, Peningkatan kompetensi managerial prajuru desa adat, Peningkatan kapasitas sumber daya manusia pengelola LPD. 
2. Pelatihan Peningkatan Kompetensi Manajerial Prajuru Desa Adat melalui pelatihan dan pendampingan prajuru adat tentang cara membuat perarem (awig-awig) atau aturan desa adat yang diberikan oleh Dr.Ketut Sudantra SH, MH dilaksanakan pada tanggal 27 juni 2017.

3. Pelatihan tentang administrasi umum penyelenggara desa adat yang diberikan oleh Prof. Dr. Wayan P. Windia,SH., MSi.

4. Peningkatan kapasitas sumberdaya manusia pengelola LPD melalui pelatihan dan pendampingan dalam pembuatan laporan atau tata kelola keuangan LPD yang diberikan oleh Bapak I Kt. Tantra dari Bank Kanti dilaksanakan pada tanggal 7 juli 2017.

5. Program IbW disambut baik oleh Pemda Kabupaten Gianyar beserta jajarannya dan mitra, mereka sangat mendukung pelaksanaan program tersebut guna mengatasi permasalahan yang sedang dihadapi. Prajuru desa adat sekabupaten Gianyar yang jumlahnya 35 orang tetapi karena ada kesibukan di beberapa desa sehingga yang bisa hadir mengikuti pelatihan adalah 21 orang $(60 \%)$. Mereka diberikan makalah tentang kegiatan pelatihan yang dilaksanakan dan mereka sangat senang dan serius mengikuti pelatihan dari awal dan aktif berdiskusi tentang administrasi umum penyelenggara desa adat, berdiskusi tentang tata kelola keuangan prajuru, tata cara pembuatan prarem sampai waktunya selesai.

6. Rancang bangun perbaikan Proses Produksi Kerajinan Patung Padas cor komposit. (aplikasi material cor padas dari daur ulang limbah sisa-sisa kerajinan patung padas). Perbaikan dilakukan pada tanggal 15 Agustus 2017 melalui pelatihan yang diikuti oleh 20 orang pengerajin untuk membuat desain/cetakan patung dan pemberian alat-alat untuk membuat cetakanpatung padas dan alat untuk membuka cetakan patung.

\section{KESIMPULAN DAN SARAN}

\subsection{Kesimpulan}

Berdasarkan hasil kegiatan program IbW di Desa Batubulan dan Singapadu untuk tahun II dapat disimpulkan sebagai berikut :

1. Kegiatan IbW ini untuk tahun ke II sudah berjalan dengan baik seperti adanya hutan adat taru pramana dan tanaman /pohon buah lokal .

2. Sudah berhasil memproduksi patung padas dari padas cor komposit .

3. Revitalisasi dan rekonstruksi seni tradisi tari jogged pingit.

4. Pelatihan prajuru dalam pembuatan prarem (peraturan) desa dan pembuatan laporan keuangan bagi pengelola LPD

\subsection{Saran}

IbW Batubulan dan Singapadu perlu dilanjutkan untuk tahun ke -3 karena sangat dibutuhkan oleh masyarakat. 


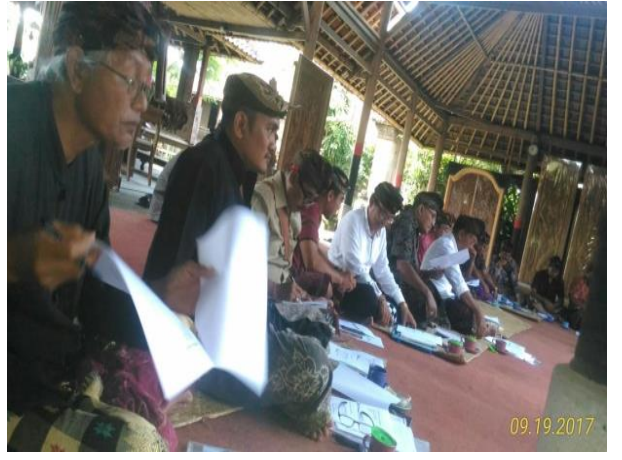

Gambar 1. Peserta pelatihan Prajuru Desa Adat

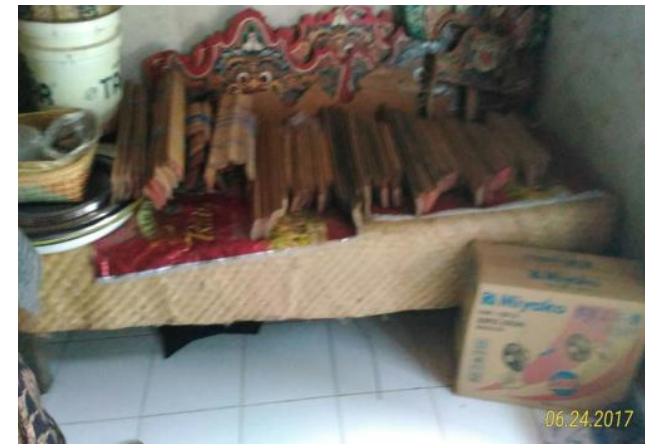

Gambar 3. Rekonstruksi dan revitalisasi seni tradisi jogged pingit

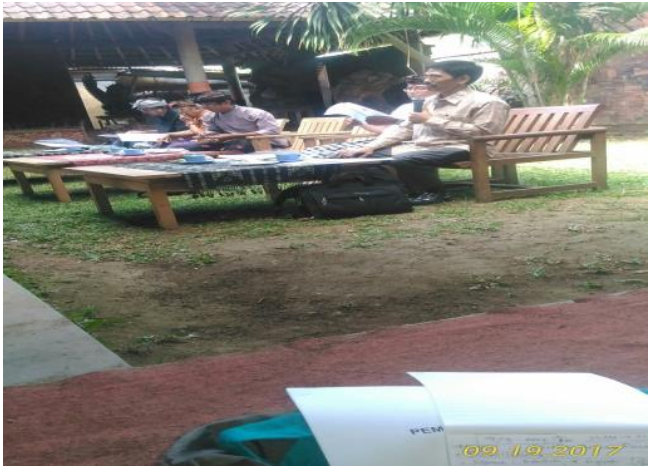

Gambar 2. Pelatihan Penyusunan Laporan Keuangan LPD

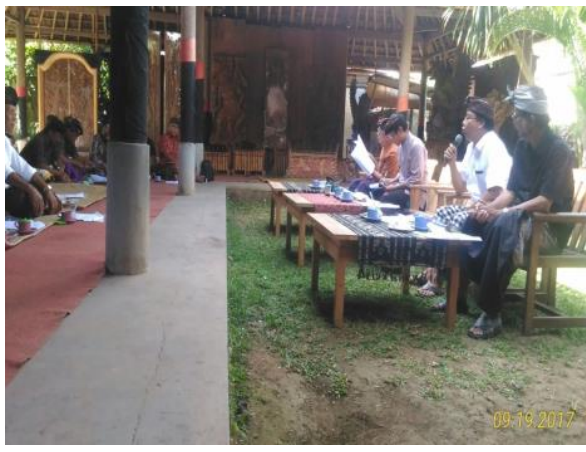

Gambar 4. Pelatihan Pembuatan Awig-awig (perarem) Desa Adat

\section{UCAPAN TERIMA KASIH}

Penulis menyampaikan terimakasih yang sebesar-besarnya kepada Direktorat Riset dan Pengabdian kepada Masyarakat Kemenristek Dikti atas dana yang diberikan, Ketua Lembaga Pengabdian kepada Masyarakat Universitas Udayana, Dekan Fakultas Pertanian serta Pemda Kabupaten Gianyar yang telah membantu kelancaran kegiatan ini.

\section{DAFTAR PUSTAKA}

Sardiana,I K.; Wayan P. Windia; Ketut Sudantra. 2011. Peta Desa Panduan Mengelola Konflik Batas Wilayah

Sardiana, I K.; Ni Made Wiasti; I Noman Wardi dan Wayan P. Windia. 2013. Etnobotani Bali 